\title{
Opintokeskuslain uudistus
}

Opintokeskusten valtionavusta annettu laki on ollut voimassa vuodesta 1976. Sen tarkistamisesta on keskusteltu 1980-luvulla aktiivisesti.

Opetusministeriön asettama pääjohtaja Erkki Ahon johtama Järjestöllisen sivistystyön toimikunta käsitteli vuonna 1983 valmistuneessa mietinnössään perusteellisesti järjestöllisen sivistystyön luonnetta ja ehdotti uutta lakia. Tämä lakiehdotus olisi toteutuessaan merkinnyt opintokeskusten lakkaamista ja niitä nyt ylläpitävien sivistysjärjestöjen tulemista suoraan lakisääteisen valtionavun saajiksi. Näin olisi ratkaistu nykyisen järjestelmän aiheuttama opintotoiminnan ja kulttuuritoiminnan erilainen tua opintokeskusten valtionavulla, kun taas sivistysjärjestöjen kulttuuritoiminta on harkinnanvaraisen valtionavun piirissä.

Ahon toimikunnan ehdotukset ovat eräiden vaiheiden jälkeen rauenneet. Riittävää yksimielisyyttä ei niiden taakse saatu; sivistysjärjestöjen kesken vallitsi kyllä muodollinen konsensus, mutta pinnan alaiset erimielisyydet olivat suuret. Tulokseksi Ahon toimikunnan työstä jäi 1980-luvun puolivälissä toteutettu ns. pikauudistus, jossa opintokeskusten valtionapulain eräitä yksityiskohtia tarkistettiin menemättä syvempiin muutoksiin. Toisena tuloksena ehkä oli uudistuksen tarpeen ilmeisyys: jotakin olisi tehtävä myöskin järjestöllisen sivistystyön lainsäädännön kehittämiseksi. 
Uusi vaihe alkoi viime vuoden jälkipuoliskolla. Valtionapuviranomaisen norminantovaltuudet tuli saada lakiin ja tämä käynnisti nopeatempoisen uudistusprosessin. Asiasta keskusteltiin viranomaisten ja opintokeskusten kesken ja virkamiesvalmisteluna syntyi lain uudistusehdotus, josta opintokeskukset antoivat lausuntonsa opetusministeriölle tammikuussa 1990.

Keskustelu lain uudistuksesta oli yksi keskeisistä teemoista Vapaan sivistystyön yhteisjärjestön ja opintokeskusten yhteistyötoimikunnan järjestämässä symposiumissa 27.2.90. Keskustelussa kävi ilmi, että varsin monia opintokeskusten tärkeinä pitämiä asioita oli otettu jo lausunnon kohteena olevaan ehdotukseen. Sitä on ilmeisesti vielä tarkennettu joissakin asioissa, joihin lausunnoissa on kiinnitetty huomiota.

Symposiumissa tunnelmana oli aidompi konsensus kuin kertaakaan 1980-luvulla: lakiehdotus näyttää olevan menossa eteenpäin opintokeskusten ja niiden takana olevien sivistysjärjestöjen yhteisymmärryksen saattelemana.

Lain uudistusehdotuksessa on eräät perustavat tekijät jätetty ennalleen. Opintokeskukset säilyvät valtionavun saajina eikä valtionapujärjestelmän menoperusteisuuteen kosketa. Kyseessä ei kuitenkaan ole vain pieniä yksityiskoh. tia koskeva uudistus.

Opintokeskuksen tarkoitusta koskeva pykälä ehdotetaan muutettavaksi siten, että yleissivistävän koulutuksen ohella myös ammatillinen jatko- ja täydennyskoulutus tulee mahdolliseksi.

Toiminnan kytkeytyminen pääosin kansalaisjärjestötoimintaan tulee ilmeisesti mainituksi joko laissa tai sen perusteluissa. Opintokeskusten omaleimaisuus vahvistuu tästä. Suomen kansalaisuus toimintaan osallistumisen ehtona poistuisi, millä on periaatteellista merkitystä esimerkiksi Suomessa olevia pakolaisia ajatellen.

Toinen olennainen muutos koskee opintokeskusten ominta toimintamuotoa, opintokerhoja. Opintokerhotoiminta on pitkään voinut huonosti ja etäänä keskeisenä syynä tähän on ollut sen valtionavun jälkeenjääneisyys. Opintokerhojen toimintasäännöksiä yksinkertaistetaan ehdotuksessa huomattavasti. Laissa tai asetuksessa ei enää yksityiskohtaisesti luetella opintokerhon valtionapuun oikeuttavia menoja, vaan näitä olisivat "opintokerhon työskentelyn kannalta tarpeelliset ja kohtuulliset menot". Opintokerhon toimintaehtoja on myös väljennetty vähentämällä opintokokousten minimimäärä kymmenestä kuuteen ja keventämällä raskaana pidettyä paperisotaa. Oppitunteja tulee kuitenkin edelleen olla vähintään kaksikymmentä. Ehdotettu uusi laki antaisi toteutuessaan myönteisen kehityssysäyksen opintokerhotoiminnalle.

Viranomaisen norminantovaltuutta koskeva ehdotus herätti kritiikkiä opintokeskuksissa. Useat katsoivat kouluhallitukselle annettavan ehdotuksessa liiaksi määräysvaltaa, koska viranomainen olisi voinut valtionavun käyttöä koskevan valvonnan lisäksi antaa määräyksiä myös toiminnan järjestämisestä. Tiettävästi tämä jälkimmäinen valtuus onkin jatkossa poistettu ehdotuksesta. Näin on saavutettu opintokeskusten tärkeänä pitämä tasapaino viranomaisten tehtävänä olevan valtionapujen käytön valvonnan ja vapaan kansalaistoiminnan autonomian välillä — näiden kahden myllynkiven välissähän opintokeskuksia jauhetaan.

Edellä mainitun lisäksi ehdotuksessa on selkeytetty valtionapulakia teknisesti ja pyritty viranomaisten päällekkäisen työskentelyn poistamiseen sekä päätös- ja harkintavallan siirtämiseen organisaatiossa alaspäin. Tässä on jossakin määrin onnistuttu.

Pyrkimyksenä on myös menettelytapojen yksinkertaistaminen ja turhien ehtojen poistaminen. Tässä suhteessa opintokeskuksilla on ollut yhtä ja toista valittamisen aihetta, varsinkin erilaisten valtionaputilitysten yksityiskohtaisuudesta johtuen. Eräänä pienenä mutta pahasti hiertävänä asiana on ollut kurssilaisten matkakustannuksia koskevien säännösten soveltaminen. Toivottavasti tässä ja muissa sinänsä pienissä mutta käytännön toimintaan paljon vaikuttavissa yksityiskohdissa on päästy eteenpäin lakiehdotusta viimeisteltäessä.

Toivoa sopii, että uusi opintokeskuslaki ja -asetus eivät juutu matkalle, vaan ne saadaan voimaan jo vuoden 1991 alusta. Siksi merkittävästä myönteisestä muutoksesta tässä on kysymys opintokeskusten harjoittaman aikuiskasvatustyön kannalta - osoittaahan tätä myös hämmästyttävä konsensus, joka vihdoinkin näyttää löytyneen järjestöllisen sivistystyön monella tavoin jännitteisessä kentässä.

HEIKKI TOIVOLA 